\title{
Metatony, S-constituent linkage, and cognate objects
}

\author{
Ronald P. Schaefer \& Francis O. Egbokhare*
}

\begin{abstract}
We examine metatony and its grammatical conditioning in an under described Edoid language of West Africa. In Emai, metatony on verbs is signaled by perfective suffix $-i$ with underlying high tone. With a following adjunct, tone on this suffix is high and retained. When clause final, $-i$ is retained but with low tone. When followed by a verb argument, the $-i$ suffix is prohibited. Verbs with a following Sconstituent exhibit metatonic asymmetry. Class one verbs prohibit suffix $-\imath$, treating $S$-constituents as verb arguments. Class two verbs require high tone $-i$, as if their $S$ constituent were an adjunct. When these same class two verbs occur with an immediately following cognate object nominal, they prohibit suffix $-i$. We interpret this asymmetric behavior of class two verbs in terms of boundary permeability (Berg 2014). We posit that class two forms are transitive and that their S-constituent derives historically from a complex Noun S-constituent structure that has become truncated and assumed a simple S-constituent form, having lost its erstwhile "cognate object noun." It is thus the strict boundary for transitivity imposed by perfective suffix $-i$ that signals a weakened status of S-constituents with class two verbs.
\end{abstract}

Keywords. metatony; S-constituents; cognate objects; boundary permeability; Emai; Edoid

1. Introduction. Metatony in Africa is an interface process where tonal and segmental exponents vary according to syntactic conditions (Hyman and Lionnet 2012). It has been described for some Bantu languages (Meeussen 1967, Nurse 2008, Hyman 2017, 2020). For this paper we describe conditions for metatony in an under described language of Nigeria's Edoid group, which is non-Bantu.

The term metatony was initially used in Proto-Bantu studies to characterize the unique tonal behavior for final vowel of an infinitive (Meeussen 1967). The class $15 \mathrm{ku}$-infinitive has the lexical form kù-sèp-à 'to laugh (at)' with low tone on final vowel à. When immediately followed by a direct object, final vowel tone is high: kù-sèp-á mfùmù 'to laugh at the chief.' On the other hand, when immediately followed by a genitive nominal, infinitive final vowel tone is low: kùsèp-à kwă-mbwá 'the laugh of the dog.' In Proto-Bantu, metatony's vowel alternation is triggered by presence of an argument nominal in immediate after verb position.

Subsequently, metatony was extended to describe tonal alternations in certain conjugated verb forms that did not involve an infinitive. Hyman and Lionnet (2012), for example, investigated Abo tone in constructions where an immediate after verb constituent was either a direct object or a non-object. A verb like sìnsè 'count' has a final lexical low tone. This low is retained

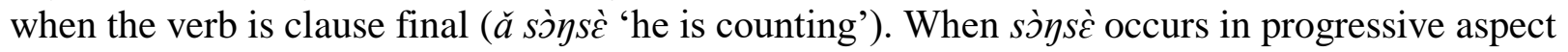
with an immediately following direct object, its final vowel shows high tone (ă sòysé mó $\downarrow n i$ 'he is counting money'). From these and other examples, Hyman and Lionnet concluded that in the

\footnotetext{
* Data incorporated in this paper derive from sponsorship by the National Science Foundation, (BNS \#9011338 and SBR \#9409552), the Department of State (CUAP ASJY 1333), and the National Endowment for the Humanities (PD-50004-06). Authors: Ronald P. Schaefer, Southern Illinois University Edwardsville (rschaef@siue.edu) and Francis O. Egbokhare, University of Ibadan (foegbokhare@yahoo.com).
} 
progressive Abo had an underlying suffix on the verb that consisted solely of a floating high low tone (-'HL) morpheme that linked to an immediately preceding lexical tone on the verb under the direct object condition.

2. Metatony in Emai. In the Edoid language Emai, metatony signals the relational nature of a verb to an immediately following constituent. The principal exponent is segmental suffix $-i$ and its tone values, high or low. As a mark of perfective (PFV) aspect, $-i$ spreads its high tone over a preceding toneless verb stem after which tone and segment dissolve or remain intact, depending on their immediately following constituent. In clausal constructions, perfective $-i$ co-occurs with tense categories in pre-verb-stem position that express past, present and future along with two degrees of temporal distance (remote and near).

We illustrate patterns of Emai metatony with bivalent verbs gbe 'hit' and $o$ 'enter.' Both are lexically toneless, as is the norm for verbs throughout Edoid (Elugbe 1989). Each verb is subcategorized for a following direct object or oblique object. First we consider verb gbe 'hit' and the effect of variable positioning of its direct object argument on underlying suffix $-i$. When $g b e$ is followed by its argument, the high tone of perfective suffix $-i$ spreads onto the toneless verb, which shows as high, after which tone and segment dissolve.

$\begin{array}{llll}\text { j́ } & \downarrow \text { gbé } & \text { ólì } & \text { ìbè. } \\ \text { 3SG } & \text { RPST } \text { Lhit\PFV } & \text { SG:ART } & \text { drum }\end{array}$

'He hit the drum.'

When an adjunct (òḋ̀ 'yesterday') immediately follows gbe, the high tone of suffix $-i$ spreads onto the toneless verb and remains attached as high.

$$
\begin{aligned}
& \text { émé' ó }{ }^{\natural} \text { gbé-í òdè? } \\
& \text { what 3SG RPSThit-PFV yesterday } \\
& \text { 'What did he hit yesterday?' }
\end{aligned}
$$

When verb gbe is clause final, suffix - $i$ spreads its high tone to the verb but appears at the surface as a low tone.

$$
\begin{aligned}
& \text { émé ó } \quad{ }^{\text {gbé-ì? }} \\
& \text { what 3SG RPST hit-PFV } \\
& \text { 'What did he hit?' }
\end{aligned}
$$

We turn now to perfective suffix - $i$ as it relates to verb $o$ 'enter' and its oblique object marked by locative $v b i$. This locative argument exhibits variable positioning. When it immediately follows $o$, the high tone of perfective $-i$ spreads onto the preceding verb and dissolves at the surface.

$$
\begin{aligned}
& \text { j } \quad \text { ó vbì ìwè. } \\
& \text { 3sg RPSTlenterlPFV LOC house } \\
& \text { 'He entered the house.' }
\end{aligned}
$$

When an adjunct (òdè 'yesterday') immediately follows $o$, perfective -í spreads its high tone onto the verb and remains at surface level with high tone.

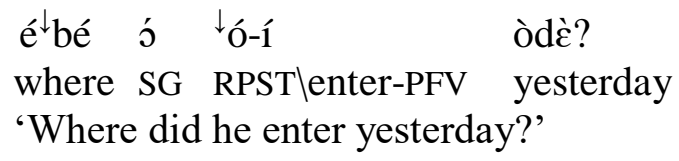


When verb $o$ is clause final, suffix $-i$ spreads its high tone onto the verb, remains at the surface but manifests tone that is low.

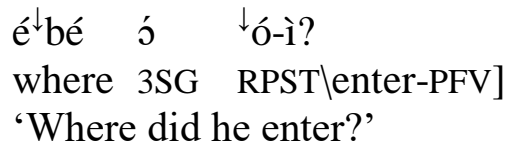

3. Metatony for verbs with following S-constituent. Perfective suffix - $i$ and metatony are not confined to verbs with a following nominal argument constituent. Some verbs with an immediately following S-constituent also exhibit metatony. For purposes of discussion, we will say here that verbs that do exhibit suffix $-i$ with following S-constituents are intransitive; those that do not are transitive. That is, transitivity type appears to determine whether verbs with an immediately following S-constituent manifest surface level perfective $-i$ with high tone.

Transitive verbs include $o o$ 'think,' $\varepsilon g b e$ 'assume,' and mic 'realize'. When immediately followed by indicative $k h i$ S-constituents, verbs of this class do not exhibit a surface level perfective suffix -í. Each treats an S-constituent in the same manner as other verbs, e.g. gbe 'hit' and $o$ 'enter,' treated their direct or oblique object. An S-constituent with verbs like $o o$ 'think' serves as an argument; as such, perfective suffix $-i$ is prohibited at the surface.
a. ì óó
khí ólì òkpòsò gbé
દ́nyè.

I NPST think $\backslash P F V$ IND the woman NPSTlkilllPFV snake

'I thought that the woman has killed a snake.'

b. ó k'gbé khì òkpòsò gbé ófè.

he RPSTlassumelPFV IND woman NPSTlkilllPFV rat

'He assumed that a woman has killed a rat.'
c. ì míć
khì òjè nwú
íbàtà
móć.
I NPST $\backslash$ find $\backslash P F V$ IND Oje NPST $\backslash$ takelPFV shoe have
'I realized that Oje has held a shoe'

Another class of verbs exhibits a distinct metatonic pattern. In this class are anma 'agree,' $\varepsilon \varepsilon n$ 'know,' hon 'hear,' vbohic 'dream,' and ta 'speak.' Each maintains a surface level perfective suffix - $i$ with high tone when immediately followed by an $\mathrm{S}$-constituent. As a consequence, one cannot identify a khi S-constituent with these verbs as a verb argument. Their S-constituent is better viewed as a non-argument. And so the verb itself is better assessed as not transitive, that is as intransitive.
a. jo لánmá-1́
khì
òjè lí jo

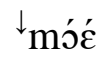
ólí úkpùn.
3SG RPSTlagree-PFV IND Oje PF 3SG RPSThavelPFV SG.ART cloth
'He agreed that it was Oje who owned the cloth.'
b. ò één-í khí ómóhé 'é ólí émàè.
3SG NPST.know-PFV IND man RPSTleatlPFV SG:ART food
'She knew that a man had eaten the food.'
c. ó 'hón-í khì òkpòsò gbé ófè.
3SG RPSThear-PFV IND woman NPSTlkill\PFV rat
'He heard that a woman has killed a rat.'

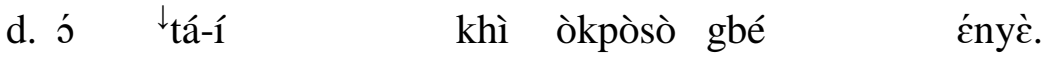
3SG RPSTlspeak-PFV IND woman NPSTlkilllPFV snake
'He said that a woman has killed a snake.' 
$\begin{array}{llllll}\text { e. j̀ } & \text { vbóhíć-í } & \text { khì } & \text { òkpòsò } & \text { gbé } & \text { ófè. } \\ \text { 3SG } & \text { NPST Idream-PFV } & \text { IND } & \text { woman } & \text { NPST kill\PFV } & \text { rat }\end{array}$

'He has dreamed that a woman has killed rat.'

In addition, we should not assume that metatony exhibited by preceding intransitive verbs is limited to S-constituents marked as indicative by khi. These same verbs, when immediately followed by a subjunctive (SUBJ) S-constituent marked by $l i$, retain perfective $-i$ with high tone at the surface. S-constituent type does not restrict metatony with intransitive verbs.
a. j’ لánmá-í
lí ókpósó gbè ólí
ófè.
3SG RPSTlagree-PFV SUBJ woman kill SG.ART rat
'He agreed that a woman should kill the rat.'
b. ó \tá-í lí ókpósó gbè ólí ófè.
3SG RPSTlsay-PFV SUBJ woman kill SG.ART rat
'He said that a woman should kill the rat.'

Verbs of the second class, which we have identified as intransitives, behave as otherwise expected with respect to perfective - $i$ suffix and its tone. When an uncontroversial non-argument adjunct, for example temporal noun òdè 'yesterday,' occurs immediately after $t a$, then the high tone of suffix $-i$ spreads onto the preceding verb (which recall is lexically toneless), remains high, and appears at the surface.

$$
\begin{aligned}
& \text { é }{ }^{\downarrow} \text { mé' ó } \downarrow_{\text {tá-1́ }} \quad \text { òdè? } \\
& \text { what 3SG RPSTlsay-PFV yesterday } \\
& \text { 'What did he say yesterday?' }
\end{aligned}
$$

When verb $t a$ is clause final, that is, when it is not immediately followed by a within-clause constituent, $-i$ high tone spreads onto toneless $t a$, becomes low, and remains at the surface.

$$
\begin{aligned}
& \text { é }^{\downarrow} \text { mé' ó } \downarrow_{\text {tá-ì? }} \\
& \text { what 3SG RPSTlspeak-PFV } \\
& \text { 'What did he say?' }
\end{aligned}
$$

To this point we have evidence that Emai linguistic patterns related to metatony and verb Sconstituents are constrained in two ways. One restriction concerns surface level presence of underlying perfective suffix $-i$. Its occurrence at the surface appears related to verb transitivity. Transitive verbs prohibit retention of perfective - $i$ when they are immediately followed by an Sconstituent argument, but not when followed by a non-argument. In contrast, intransitive verbs, which by definition do not subcategorize for a following argument, retain perfective $-i$ at the surface. A second restriction concerns tonal realization of suffix $-i$. It varies according to nature of the constituent in immediate after verb position. When this space is occupied by a withinclause constituent (which is not an argument of the verb), suffix tone remains high. When the immediate after verb site is vacant, i.e. verb is clause final, suffix tone becomes low.

Canonical intransitive verbs that do not permit $S$-constituents support the second restriction, not the first. The verb muzan 'stand' in (12a-b) shows perfective suffix $-i$ at the surface. When immediately followed by a within-clause constituent such as a (non-argument) locative, -i manifests high tone. When not followed by any such constituent, $-i$ appears as low. 

$\begin{array}{llll}\text { a. ó } & { }^{\downarrow} \text { múzán-í } & \text { vbí } & \text { úkpòdè. } \\ \text { 3SG } & \text { RPSTlstand-PFV } & \text { LOC } & \text { road }\end{array}$
'He stood on the road.'
b. ó $\quad{ }^{\downarrow}$ múzán-ì.
3SG RPST \stand-PFV
'He stood/waited.'

4. Linkage and metatony for verbs with following nominal constituents. The involvement of transitivity in the relation between verbs and their S-constituents is not as straightforward as it may seem. After all, it is not transitivity as subcategory type assigned to a verb that constrains surface level occurrence of perfective suffix - $i$. Examples 1-6 with verbs $g b e$ and $o$ showed this. Instead, it is presence of a verb argument in immediate after verb position that constrains surface occurrence of suffix - $i$. S-constituents with verbs of the $o o$ 'think' type occupy immediate after verb position. They prohibit retention of suffix $-i$, as expected of arguments. Verbs of the $t a$ 'speak' type also show an S-constituent in immediate after verb position. But they retain suffix -i at the surface. For $t a$, the S-constituent in immediate after verb position, especially when compared to the S-constituent of transitive verbs like $o o$, exhibits a distinct metatonic pattern. It does not manifest the character of a verb argument. If S-constituents with $t a$ are not verb arguments, what is their status?

We briefly examine this status issue from the perspective of linkage. One option confines attention to linkage between verb and clause constituent. Several attachment sites for linkage defined in this manner are discussed in various studies included in Gast and Diessel (2012). Following Foley and Van Valin (1984), Van Valin and LaPolla (1997) and Van Valin (2005, 2007), most assume a clause structure that is layered. There are three possible juncture sites where a clause might attach to a host: nucleus (verb), core (verb plus arguments), or clause (adjunct). Under these assumptions, there is one immediate response to the status issue. For S-constituents with one class of verbs, those that are transitive, the attachment site would be at the core layer. As verb arguments, S-constituents with oo 'think' would reflect core juncture. Such a linkage assignment would be consistent with verb oo and its metatonic behavior. In contrast, the attachment site for S-constituents with the second class of verbs, intransitives like $t a$ 'speak,' would more likely be the clause layer, where sentence level adjuncts append. A linkage assignment of this nature would be consistent with ta metatony. Using this split linkage perspective, Sconstituents with transitive $o o$ would be arguments and those with intransitive $t a$ would be adjuncts. Equally important, the metatony facts would support this split linkage interpretation.

Confining attention only to clause linkage, however, may not be the most advantageous strategy moving forward. It leads us to assume that verbs like $t a$ 'speak' are syntactically aberrant only with regard to a following S-constituent. As it happens, there are additional structures that bear on linkage relations. Intransitive verbs of the $t a$ class that allow an S-constituent also occur with a following nominal constituent, as in (13).

$$
\begin{aligned}
& \text { a. ó 'tá } \\
& \text { 3SG RPSTlspeaklPFV words } \\
& \text { 'She spoke / uttered words.' } \\
& \text { b. '́ j̀ hòn énòn. } \\
& \text { 3SG HAB hearlIPFV ear } \\
& \text { 'The man hears well (with his ear).' }
\end{aligned}
$$


As is evident, these nominals are etymologically related to their verbs. They are cognate objects (Eitelmann and Mondorf 2018). Commonality of phonological form with corresponding verb is not the only property of these nominals. They differ syntactically from canonical objects, whether direct or oblique. Relevant evidence is particularly noticeable when nominals of verbs in class two are compared to nominals that follow verbs from class one. In (14a-b), nominals associated with class one verbs $o o$ and mic can be modified by an adnominal, such as the singular definite article. In contrast, cognate objects do not permit any adnominal (14c).
a. j̀ óó
ólì ìnyèmì.
3SG NPST think.about $P F V$ SG.ART matter
'She has thought about the matter.'
b. j ' míć ólí úkpùn.
3SG RPST \ind \PFV SG.ART SG.cloth
'He found the cloth'
c. *j b́ b́lì étà.
3SG RPST \speak\PFV SG.ART words
'She spoke / uttered the words.'

In addition, we note that contrary to $\mathrm{S}$-constituents, nominal constituents that follow ta-like verbs do not permit perfective suffix - $i$ at the surface level, as in ungrammatical (15) vis-à-vis grammatical (13a). That is, $t a$ and its class do not treat their immediate after verb S-constituents and nominal constituents uniformly. Given that $\mathrm{S}$-constituents with $t a$ verbs triggered suffix - $i$, nominal constituents would be expected to behave similarly. They do not. The prohibition against suffix $-i$ in cognate object constructions reveals that nominal constituent étà, for example, is treated as an argument of its verb. Nominal or cognate object constituents in immediate after verb position, therefore, give every indication of being related to their verb as an argument.

$$
\begin{array}{ll}
\text { *'́ } \quad \downarrow_{\text {tá-í }} \text { étà. } \\
\text { 3SG RPSTlspeak-PFV words } \\
\text { 'She spoke / uttered the words.' }
\end{array}
$$

5. Final thoughts with boundary permeability. Now we have a conundrum. There is one class of verbs that display perfective suffix $-i$ when followed by an S-constituent but restrain this same suffix from appearing at the surface when followed by a nominal constituent. From the linkage perspective, an S-constituent as adjunct reflects clause level juncture, whereas nominal constituents as verb argument evidence core juncture. Linkage representations delineate the conundrum but do not provide insight to the broader problem of verbs (with a single cognitive sense) that display metatony with an immediately following $\mathrm{S}$-constituent but that fail to display metatony with a nominal constituent.

A different approach to the status issue arises from the perspective of boundary permeability (BP), as articulated by Berg (2014). Boundary permeability as a typological parameter bears on the association of a verb to its subcategorization frames. Languages with strict (non-permeable) boundaries tend toward a consistent form-to-function mapping that is isomorphic (one-to-one relation), while those with soft (permeable) boundaries trend away from isomorphism in their mapping of form to function. Furthermore, Berg proposes that differences in boundary permeability reflect differences in the occurrence and strength of inflectional morphology. Inflectional elements establish a divide between syntax and the lexicon such that robust inflection leads to strict boundaries and non-robust inflection to softer boundaries. In the Emai instance, inflection 
and prosodic behavior converge on the issue of verb subcategorization: intransitive Sconstituents with metatony by suffix vs. transitive nominal constituents without metatony by suffix.

These facts appear less puzzling if one assumes that Emai is a strict boundary language that seeks one-to-one relations for its mapping of form-to-function. The behavior of $o o$ 'think' verbs supports an assumed strong preference for non-permeable boundaries. The dissonance pertaining to subcategorization that is evident with a ta class verb reflects a weaker preference for nonpermeable boundaries. Permeability with respect to subcategorization is evident in the selection of a transitive frame without metatony for nominal constituents serving as cognate objects but an intransitive frame with metatony for S-constituents.

Let us redefine our problem. First, assume that Emai is a strict boundary language with strong inflection (perfective suffix $-\hat{\imath}$ ) and that class-two verbs like $t a$ are uniformly transitive. Second, assume that an S-constituent associated with class two verbs derives diachronically from a more complex Noun S-constituent structure, which in the canonical instance is headed by a noun (Gast and Diessel 2012), as in the English The fact that he was angry. Under this hypothesis metatony with $\mathrm{S}$-constituents and ta-like verbs could be viewed as signaling that the immediate after verb position is not occupied by a verb argument, which would be consistent with metatonic practice. Were the Noun S-constituent structure to exist synchronically, it might appear as the hypothetical form in (16a). Synchronically, Emai shows no Noun S-constituent structures (Schaefer and Egbokhare 2017). However, there is evidence that some verbs of class two require an internally complex constituent for nominals in direct object position, as in (16bd), where the notional object noun is preceded by a classifier-like noun. Simple nominals in direct object position, in contrast, are deemed ungrammatical $(16 \mathrm{c})$.
a. ?’ ‘́ tátá khì òkpòsò gbé ćnyè. 3SG RPSTlspeak\PFV words IND woman NPST/kill\PFV snake
'He spoke words that a woman has killed a snake.'
b. j̀ ó hòn ìkhúéé ólí jvbèkhàn.
3SG PROG hearlIPFV sound SG:ART youth
'She is hearing the youth.'
c. *j ó hòn ólí óvbèkhàn.
3SG PROG hearlIPFV SG:ART youth
'She is hearing the youth.'
d. ó ò hòn ùróó émáì.
3SG HAB hearlIPFV language Emai
'She understands Emai.'

It may be therefore that boundary permeability with respect to subcategorization should not be viewed exclusively as a system wide property but as a subsystem feature subject to constraints not always predictable from the extant lexicon or morphosyntax. Initially this may seem counter intuitive given the predominant view of languages in West Africa, which is their tendency toward a morphosyntax that is isolating and lacking in inflection. Nonetheless, as we go forward in assessing the Emai grammatical system, the question should not be general and symmetrical, e.g. where else do we find subcategorization dissonance in the domain of transitivity; rather, it should be more specific and asymmetrical, where else do we find intransitive subcategorization by inflectional resources for an otherwise strict transitivity boundary. 


\section{References}

Berg, Thomas 2014. Boundary permeability: A parameter for linguistic typology. Linguistic Typology 18(3). 489-531. https://doi.org/10.1515/lingty-2014-0020.

Eitelmann, Matthias \& Britta Mondorf. 2018. Cognate objects in language variation and change. In Rita Finkbeiner \& Ulrike Freywald (eds.), Exact repetition in grammar and discourse. 200-230. Berlin: DeGruyter.

Elugbe, Ben. 1989. Comparative Edoid: Phonology and lexicon. Port Harcourt: University of Port Harcourt Press.

Foley, William A. \& Robert D. Van Valin Jr. 1984. Functional syntax and universal grammar. New York: Cambridge University Press.

Gast, Volker \& Holger Diessel. 2012. The typology of clause linkage: Status quo, challenges, prospects. In Volker Gast \& Holger Diessel (eds.), Clause linkage in cross-linguistic perspective, 1-36. Berlin: Mouton de Gruyter.

Hyman, Larry M. 2017. Disentangling conjoint, disjoint, metatony, tone cases, augments, proso$\mathrm{dy}$, and focus in Bantu. In Jenneke van der Wal \& Larry M. Hyman (eds.), The conjoint/disjoint alternation in Bantu. 100-121. Berlin/Boston: De Gruyter Mouton.

Hyman, Larry M. 2020. Prosodic asymmetries in nominal and verbal phrases in Bantu. Keynote, $6^{\text {th }}$ International Conference on Phonetics and Phonology, National Institute for Japanese Language and Linguistics, December 2019.

Hyman, Larry M. \& Florian Lionnet. 2012. Metatony in Abo (Bankon), A42. In Michael R. Marlo, Nikki B. Adams, Christopher R. Green, Michelle Morrison \& Tristan M. Purvis (eds.), Selected proceedings of 42nd Annual Conference on African Linguistics: African Languages in Context, 1-14. Somerville, MA: Cascadilla Proceedings Project.

Meeussen, A. E. 1967. Bantu grammatical reconstructions. Africana Linguistica 3.79-121.

Nurse, Derek. 2008. Tense and aspect in Bantu. New York: Oxford University Press.

Schaefer, Ronald P. \& Francis O. Egbokhare. 2017. A grammar of Emai. [Mouton Grammar Library Series]. Berlin: Mouton de Gruyter.

Van Valin, Robert D. 2005. Exploring the syntax-semantics interface. New York: Cambridge University Press.

Van Valin, Robert D. 2007. Recent Developments in the role and reference grammar theory of clause linkage. Language and Linguistics 8. 71-93.

Van Valin, Robert D. and Randy J. LaPolla. 1997. Syntax - Structure, meaning and function. New York: Cambridge University Press. 